\title{
Detection of Lead in Human Teeth by Exposure to Aqueous Sulfide Solutions
}

\author{
Akiyoshi SUGAWARA*, Joseph M. ANTONUCCI ${ }^{+}$, George C. \\ PAFFENBARGER $^{*}$ and Masayoshi OHASHI*
}

(Received 19 December 1988 and accepted 21 January 1989)

Key words: discoloration, contamination of human teeth, $\mathrm{Na}_{2} \mathrm{~S}$ solution

\begin{abstract}
A recent study has shown that the presence of lead $(\mathrm{Pb})$ as well as other base metals in esthetic restorative materials, especially dental cements, is detectable by color shifts induced by exposure of hardened specimens to a $0.1 \%(\mathrm{w} / \mathrm{v})$ aqueous solution of sodium sulfide, $\mathrm{Na}_{2} \mathrm{~S}$. The present study was initiated to determine the applicability of this simple exposure test to the detection of $\mathrm{Pb}$ in human teeth. Extracted whole teeth as well as sectioned, thin specimens were exposed first to either a $0.01 \%$ or a $0.001 \%(\mathrm{w} / \mathrm{v})$ aqueous solution of lead nitrate, $\mathrm{Pb}\left(\mathrm{NO}_{3}\right)_{2}$, at $37^{\circ}$ $\mathrm{C}$ for $24 \mathrm{~h}$. After rinsing with distilled $\mathrm{H}_{2} \mathrm{O}$ and a subsequent $24 \mathrm{~h}$ exposure to the $0.1 \% \mathrm{Na}_{2} \mathrm{~S}$ solution at $37^{\circ} \mathrm{C}$, the tooth specimens were examined visually and by a dental color analyzer for color changes. The latter color measurements were evaluated by the Lab system of Hunter, and the color difference, $\Delta \mathrm{E}$, was determined. Neither control specimens exposed to distilled $\mathrm{H}_{2} \mathrm{O}$ only or to $0.1 \% \mathrm{Na}_{2} \mathrm{~S}$ only exhibited any significant change in appearance after $24 \mathrm{~h}$ of storage at $37^{\circ} \mathrm{C}$. However, specimens exposed first to the $\mathrm{Pb}\left(\mathrm{NO}_{3}\right)_{2}$ solutions showed discernible $\Delta \mathrm{E}$ values after exposure to the $\mathrm{Na}_{2} \mathrm{~S}$ solution. $\Delta \mathrm{E}$ was greatest for specimens exposed to the more concentrated $\mathrm{Pb}\left(\mathrm{NO}_{3}\right)_{2}$ solution. Most of the discoloration in both thin and intact tooth specimens was confined to the outermost layers of the tooth structure. For the intact specimens, the greatest degree of discoloration occurred in the cementum, the most permeable part of the tooth structure.
\end{abstract}

\section{Introduction}

Previous studies dealing with the occurrence of $\mathrm{Pb}$ in human teeth have revealed that this element is widely prevalent as a minor contaminant ${ }^{[1,2]}$. Dentin has about three times the $\mathrm{Pb}$ content found in enamel. The outer portion of the enamel exhibits the highest concentrations of this metal. It has also been found that the $\mathrm{Pb}$ content is significantly greater in older teeth, e. g. 50 years, $\cong 550 \mathrm{ppm}$, than in younger teeth.

* 菅原明喜、大橋正敬：Department of Dental Materials, Nihon University School of Dentistry, 1-8-13, Kanda-Surugadai, Chiyoda-ku, Tokyo, 101 JAPAN.

+ Polymer Division, Dental and Medical Materials Group, National Institute of Standards and Technology, Gaithersburg, MD 20899, U. S. A.

\# Paffenbarger Research Center, National Institute of Standards and Technology, Gaithersburg, MD 20899, U. S. A.. 
In addition to the biological implications of these findings, there is the possibility of gradual tooth discoloraion occurring with age due to the formation of dark-colored lead salts, e. g. lead sulfide $(\mathrm{PbS})$. This potential for discoloration of tooth structure is further augmented in oral environments that generate relatively high concentrations of sulfide ion or related chemical species due to putrefaction (e. g. from diets comprising sulfur-containing foods).

In previous studies it was shown that $\mathrm{Pb}$ and other base metal contaminants present in esthetic dental restorative materials, especially dental cements, were readily detectable by exposure to an atmosphere of $\mathrm{H}_{2} \mathrm{~S}$ or to a dilute $(0.1 \% \mathrm{w} / \mathrm{v})$ aqueous solution of sodium sulfide, $\mathrm{Na}_{2} \mathrm{~S}^{[3]}$.

The present preliminary study was initiated in order to determine if the technique of using $0.1 \% \mathrm{Na}_{2} \mathrm{~S}$ solution for the detection of metal contaminants in cement and composite materials was also applicable as a method for detection of $\mathrm{Pb}$ or other base metals in contaminated teeth.

\section{Materials and Methods}

The chemicals used in this study were sodium sulfide, $\mathrm{Na}_{2} \mathrm{~S} \cdot 9 \mathrm{H}_{2} \mathrm{O}$ (ACS grade, Alfa Products, Danvers, MA), lead nitrate, $\mathrm{Pb}\left(\mathrm{NO}_{3}\right)_{2}$ (J. T. Baker Chemical Co., Phillipsburg, NJ), and freshly extracted human permanent teeth, from subjects approximately 20-40 years old.

I . Preparation of Specimens

A) Sectioned Tooth Specimens

By means of a water-cooled diamond disc (Slicer MC-501D, Maruto Co., Tokyo, Japan), some of the tooth specimens were sectioned into thin pieces, approximately $1.0 \mathrm{~mm}$ thick.

Individual sectioned specimens were then immersed in the following aqueous media for $24 \mathrm{~h}$ at $37^{\circ} \mathrm{C}$ : (1) distilled water (primary control), (2) $0.1 \% \mathrm{Na}_{2} \mathrm{~S}$ at $\mathrm{pH}$ 9 (secondary control), (3) $0.01 \% \mathrm{~Pb}\left(\mathrm{NO}_{3}\right)_{2}$ and (4) $0.001 \% \mathrm{~Pb}\left(\mathrm{NO}_{3}\right)_{2} \cdot(\%$ are w/v).

After removal from solutions (3) and (4), the $\mathrm{Pb}$-contaminated specimens were rinsed for $1 \mathrm{~min}$ under a stream of distilled water, dried with air for $20 \mathrm{~s}$, and immediately immersed in (2). After $24 \mathrm{~h}$ of immersion at $37^{\circ} \mathrm{C}$, the specimens were removed, rinsed with distilled water for $1 \mathrm{~min}$ and dried with a blast of air for $20 \mathrm{~s}$. B) Intact Tooth Specimens

Individual intact tooth specimens were immersed in the following aqueous media for $24 \mathrm{~h}$ at $37^{\circ} \mathrm{C}:$ (1) $0.1 \% \mathrm{Na}_{2} \mathrm{~S}$ at $\mathrm{pH} 9$ (control), (2) $0.01 \% \mathrm{~Pb}\left(\mathrm{NO}_{3}\right)_{2}$. After immersion in solution (2), the $\mathrm{Pb}$-contaminated intact tooth was rinsed for $1 \mathrm{~min}$ in a stream of distilled water, dried with air for $20 \mathrm{~s}$, and immediately immersed in (1). After immersion at $37^{\circ} \mathrm{C}$, the intact tooth specimens were removed, rinsed with distilled water for $1 \mathrm{~min}$ and dried with a blast of air for $20 \mathrm{~s}$.

The volume of each aqueous medium in A and B was $5.0 \mathrm{ml}$ (in vials sealed with Teflon-lined screw caps).

II. Measurement of Color Difference

After immersion in the $0.1 \% \mathrm{Na}_{2} \mathrm{~S}$ solution and drying with a blast of air for $20 \mathrm{~s}$, both the sectioned and intact tooth specimens were immediately subjected to visual and colorimetric examination using 10 sheets of round filter paper as a white 
background.

Colorimetric examination of these specimens was performed using a dental color analyzer (Dental Color Analyzer N-S 100, J. Morita Co., Tokyo, Japan). The method of color measurement was the same as that employed by the Lab System of ADAMS and the color difference, $\Delta \mathrm{E}$, was determined by the Japanese Industrial Standard Z 8730.

Values for the Lab System are defined as follows: " $L$ " is the light index. The higher the value, the greater the lightness. The values "a" and " $b$ " are chromatic indices. A plus sign for the "a" axis indicates the red color zone and a minus sign the green color zone. A plus sign for the " $b$ " axis signifies the yellow color zone and a minus sign the blue color zone. If the coordinates of Lab values obtained from the before-after observations are assumed to be $\left(L_{1}, a_{1}, b_{1}\right)$ and $\left(L_{2}, a_{2}, b_{2}\right)$, then differences in these values are $(\Delta \mathrm{L}, \Delta \mathrm{a}, \Delta \mathrm{b})$, and $\Delta \mathrm{E}$ can be calculated from the following expression:

$$
\Delta \mathrm{E}=\sqrt{(\Delta \mathrm{L})^{2}+(\Delta \mathrm{a})^{2}+(\Delta \mathrm{b})^{2}}
$$

III. Elementary Analysis of Sectioned Specimens

An electron microprobe analyzer, EMA-SM 7 (Shimazu Co., Tokyo, Japan) was employed to detect and measure heavy metal elements $(\mathrm{Cu}, \mathrm{Fe}, \mathrm{Pb}, \mathrm{Ag}$, and $\mathrm{Hg}$ ) present in each tooth specimen. Conditions used for line analysis were as follows: accelerating voltage- $20 \mathrm{kV}$, sample current- $1 \times 10^{-8} \mathrm{~A}$, beam spot diameter$1 \mu \mathrm{m}$.

\section{Results and Discussion}

The results of this study are shown in Figs. 1-15 and Tables 1-6. Figures 7-12 and Tables 1-6 were obtained using a dental color analyzer, and Figs. 13-15 were obtained by electron microprobe line analysis. Neither the primary control specimens (exposed to distilled water only) nor the secondary control specimens (exposed to $0.1 \% \mathrm{Na}_{2} \mathrm{~S}$ solution only) exhibited any significant change in appearance of the enamel part of the specimen after storage at $37^{\circ} \mathrm{C}$ for $24 \mathrm{~h}$ (Figs. 1-4, $7-10$, Tables 1-4). The negative results obtained with the secondary controls implied that these untreated tooth specimens either had low content of $\mathrm{Pb}$ or other base metals or that the availability of any heavy metal ions for reaction with sulfide ion $\left(\mathrm{S}^{2-}\right)$ was restricted by their location in the apatitic tooth structure.

The specimens that were exposed first to the $\mathrm{Pb}\left(\mathrm{NO}_{3}\right)_{2}$ solutions immediately showed discernible color differences $(\triangle \mathrm{E})$ after exposure to the $\mathrm{Na}_{2} \mathrm{~S}$ solution. $\Delta \mathrm{E}$ was greatest in the specimens exposed to the more concentrated $\mathrm{Pb}\left(\mathrm{NO}_{3}\right)_{2}$ solution, $0.01 \%$. Most of the dark discoloration in both thin and intact tooth specimens was confined to the outermost layers of the tooth structure. In the case of the intact tooth, which was first exposed to the $0.01 \% \mathrm{~Pb}\left(\mathrm{NO}_{3}\right)_{2}$ solution, the discoloration that occurred after immersion in the $\mathrm{Na}_{2} \mathrm{~S}$ solution was greatest $(\Delta \mathrm{E}=39.3)$ in the cementum area, although slight discoloration $(\Delta \mathrm{E}=13.8)$ also occurred in the enamel (Figs. 5 and 11, Table 5). Cross-sectioning of the darkened cementum 
revealed that most of the interior portion was unchanged but that discoloration also occurred in the dentin layer of this part of the tooth (Fig. 5)

Furthermore, in the case of the intact tooth which was exposed to $0.1 \% \mathrm{Na}_{2}$ $\mathrm{S}$ solution only at $37^{\circ} \mathrm{C}$ for $24 \mathrm{~h}$, brown discoloration $(\Delta \mathrm{E}=33.3)$ occurred in the cementum area with only very slight discoloration $(\Delta \mathrm{E}=4.3)$ in the enamel area ( Figs. 6 and 12, Table 6). The results of elementary analysis of the sectioned tooth specimens (Figs. 13-15) indicated that most of the specimens contained significant amounts of $\mathrm{Cu}(0.00-0.20 \mathrm{wt} \%)$ and $\mathrm{Fe}(0.00-0.35 \mathrm{wt} \%)$ and only minor amounts of $\mathrm{Ag}$ and $\mathrm{Pb}$.

Therefore, these results suggest the possibility that the discoloration of the intact tooth, which was exposed to the $0.1 \% \mathrm{Na}_{2} \mathrm{~S}$ solution only, might be mainly caused by the formation of dark-colored sulfides of contaminating heavy metals $(\mathrm{Cu}, \mathrm{Fe}, \mathrm{Ag}$, and $\mathrm{Pb})$ already present in the tooth structure.

In earlier studies ${ }^{[3,4]}$, it was noted that for $\mathrm{Pb}$-contaminated esthetic dental materials, the rate and severity of discoloration was greatest for dental cements. Only one composite, the microfilled Isopast (commercially available in the market), which has a comparatively high water absorption and may be more easily penetrated by $\mathrm{S}^{2-}$, showed severe discoloration. The greater discoloration observed in the relatively porous cementum region of the tooth would seem to parallel these findings, i. e. the rate and severity of color formation is related to the permeability of the $\mathrm{Pb}$-contaminated specimen to $\mathrm{S}^{2-}$ or related sulfur-containing chemical species $^{[3,4]}$. Further work is now in progress to expand the scope of these findings to other metal contaminants as well as other types of dental material.

\section{Conclusions}

1) The greatest discoloration in both sectioned and intact teeth was observed for specimens that were immersed in $0.01 \% \mathrm{~Pb}\left(\mathrm{NO}_{3}\right)_{2}$ solution.

2) In the case of intact tooth specimens that were first exposed to $0.01 \% \mathrm{~Pb}$ $\left(\mathrm{NO}_{3}\right)_{2}$ solution, the greatest degree of discoloration $(\Delta \mathrm{E}=39.3)$ occurred in the cementum, the most permeable portion of the tooth structure.

3) In the case of the intact tooth which was exposed to $0.1 \% \mathrm{Na}_{2} \mathrm{~S}$ solution only, easily discernible discoloration $(\Delta \mathrm{E}=33.3)$ occurred in the cementum portion, probably due to the formation of dark-colored sulfides of heavy metals (e. g. $\mathrm{Cu}, \mathrm{Fe}, \mathrm{Ag}, \mathrm{Pb}$ ) contained in natural teeth as contaminants.

\section{References}

[1] Brudevold, F. and Steadman, L. T.: The distribution of lead in human enamel, $J$ Dent. Res., 35 (3), 430-437, 1956

[2] Mathew, M., Brown, W. E., Austin, M. and Negas, T. : Lead alkali apatites without hexad anion: The crystal structure of $\mathrm{Pb}_{8} \mathrm{~K}_{2}\left(\mathrm{PO}_{4}\right)_{6}$, J. Solid State Chem., 35, 69-76, 1980

[3] Sugawara, A. : Effect of hydrogen sulfide gas on discoloration of esthetic restorative materials, J. J. Dent. Mat., 2 (4), 381-400, 1983

[4] Sugawara, A., Antonucci, J. M. and Paffenbarger, G. C. : Discoloration of dental cements and composites in a sulfide solution, IADR Progr. \& Abstr., 63, No. 550, 1984 
Table 1 Results of discoloration 1 | (Thin Specimens)

\begin{tabular}{|c|c|c|c|c|c|c|c|}
\hline & \multicolumn{3}{|c|}{ Before } & \multicolumn{3}{|c|}{ After } & \multirow[b]{2}{*}{ E } \\
\hline & $\mathrm{L}$ & $\mathrm{a}$ & $\mathrm{b}$ & $\mathrm{L}$ & $a$ & $\mathrm{~b}$ & \\
\hline $\begin{array}{l}\text { Primary } \\
\text { Control }\end{array}$ & 63.2 & -1.5 & -22.1 & 62.1 & -1.0 & 21.9 & 1.2 \\
\hline S. D. & 1.25 & 3.56 & 0.71 & 1.20 & 2.68 & 0.15 & \\
\hline $\begin{array}{l}\text { Secondary } \\
\text { Control }\end{array}$ & 62.3 & -2.6 & -19.9 & 59.9 & -1.8 & -21.0 & 2.8 \\
\hline S. D. & 1.13 & 0.92 & 0.64 & 2.39 & 1.69 & 0.55 & \\
\hline $\begin{array}{l}0.001 \% \\
\mathrm{~Pb}\left(\mathrm{NO}_{3}\right)_{2}\end{array}$ & 57.9 & -0.5 & -18.4 & 43.0 & 2.0 & -18.6 & 15.1 \\
\hline S. D. & 1.10 & 1.02 & 0.86 & 1.12 & 1.05 & 0.66 & \\
\hline $\begin{array}{l}0.01 \% \\
\mathrm{~Pb}\left(\mathrm{NO}_{3}\right)_{2}\end{array}$ & 60.7 & -1.1 & -19.5 & 12.9 & 3.6 & -8.9 & 49.2 \\
\hline S. D. & 1.10 & 0.61 & 0.25 & 1.18 & 0.40 & 2.48 & \\
\hline
\end{tabular}

1 : : Maxillary right incisor

Table 2 Results of discoloration $\underline{3}$ | (Thin Specimens)

\begin{tabular}{|c|c|c|c|c|c|c|c|}
\hline & \multicolumn{3}{|c|}{ Before } & \multicolumn{3}{|c|}{ After } & \multirow[b]{2}{*}{ E } \\
\hline & $\mathrm{L}$ & $a$ & $\mathrm{~b}$ & L & $a$ & $\mathrm{~b}$ & \\
\hline $\begin{array}{l}\text { Primary } \\
\text { Control } \\
\end{array}$ & 67.0 & 3.2 & -25.4 & 64.4 & 4.2 & -25.6 & 2.8 \\
\hline S. D. & 2.02 & 1.25 & 2.06 & 0.85 & 0.66 & 1.46 & \\
\hline $\begin{array}{l}\text { Secondary } \\
\text { Control }\end{array}$ & 59.2 & 1.0 & -22.1 & 56.8 & 0.6 & -21.7 & 2.5 \\
\hline S. D. & 2.61 & 2.93 & 2.41 & 3.27 & 2.42 & 1.89 & \\
\hline $\begin{array}{l}0.001 \% \\
\mathrm{~Pb}\left(\mathrm{NO}_{3}\right)_{2}\end{array}$ & 60.4 & -0.5 & -24.5 & 43.4 & 2.5 & -21.3 & 17.6 \\
\hline S. D. & 2.29 & 1.36 & 0.80 & 2.21 & 0.61 & 1.35 & \\
\hline $\begin{array}{l}0.01 \% \\
\mathrm{~Pb}\left(\mathrm{NO}_{3}\right)_{2}\end{array}$ & 61.0 & -0.8 & -23.1 & 10.2 & 1.5 & -8.7 & 52.9 \\
\hline S. D. & 1.85 & 2.17 & 1.14 & 2.15 & 1.50 & 1.10 & \\
\hline
\end{tabular}

3| : Maxillary right cuspid

Table 3 Results of discoloration $\underline{4 \mid}$ (Thin Specimens)

\begin{tabular}{|c|c|c|c|c|c|c|c|}
\hline & \multicolumn{3}{|c|}{ Before } & \multicolumn{3}{|c|}{ After } & \multirow[b]{2}{*}{$\mathrm{E}$} \\
\hline & $\mathbf{L}$ & $a$ & $\mathrm{~b}$ & $\mathrm{~L}$ & $a$ & $\mathrm{~b}$ & \\
\hline $\begin{array}{l}\text { Primary } \\
\text { Control }\end{array}$ & 59.4 & 3.6 & -26.3 & 58.3 & 2.5 & -26.2 & 1.6 \\
\hline S. D. & 3.90 & 0.52 & 0.84 & 3.42 & 0.93 & 1.17 & \\
\hline $\begin{array}{l}\text { Secondary } \\
\text { Control }\end{array}$ & 61.0 & 2.9 & -23.7 & 58.5 & -2.1 & -24.5 & 5.6 \\
\hline S. D. & 6.78 & 4.71 & 1.32 & 6.19 & 3.51 & 0.79 & \\
\hline $\begin{array}{l}0.001 \% \\
\mathrm{~Pb}\left(\mathrm{NO}_{3}\right)_{2}\end{array}$ & 58.6 & -0.4 & -23.1 & 48.1 & 0.3 & -18.9 & 11.3 \\
\hline S. D. & 4.60 & 0.99 & 1.53 & 4.71 & 1.75 & 1.99 & \\
\hline $\begin{array}{l}0.01 \% \\
\mathrm{~Pb}\left(\mathrm{NO}_{3}\right)_{2}\end{array}$ & 57.3 & -2.6 & -23.3 & 9.2 & 0.6 & -7.5 & 50.7 \\
\hline S. D. & 3.12 & 3.21 & 1.69 & 2.45 & 0.59 & 1.22 & \\
\hline
\end{tabular}

$\underline{4}$ |: Maxillary left premolar 
Table 4 Results of discoloration $\underline{8}$ | (Thin Specimens)

\begin{tabular}{|c|c|c|c|c|c|c|c|}
\hline & \multicolumn{3}{|c|}{ Before } & \multicolumn{3}{|c|}{ After } & \multirow[b]{2}{*}{$\mathbf{E}$} \\
\hline & $\mathrm{L}$ & $\mathrm{a}$ & $\mathrm{b}$ & $\mathbf{L}$ & $\mathrm{a}$ & $\mathrm{b}$ & \\
\hline $\begin{array}{l}\text { Primary } \\
\text { Control }\end{array}$ & 60.0 & 3.4 & -29.7 & 56.0 & 0.2 & -30.4 & 5.4 \\
\hline S. D. & 2.61 & 2.14 & 0.40 & 3.01 & 3.91 & 1.01 & \\
\hline $\begin{array}{l}\text { Secondary } \\
\text { Control }\end{array}$ & 60.0 & 3.5 & -30.9 & 57.0 & 3.4 & -29.9 & 3.2 \\
\hline S. D. & 3.01 & 2.78 & 1.36 & 3.95 & 1.44 & 2.51 & \\
\hline $\begin{array}{l}0.001 \% \\
\mathrm{~Pb}\left(\mathrm{NO}_{3}\right)_{2}\end{array}$ & 58.4 & 1.0 & -30.5 & 31.8 & 6.9 & -23.2 & 27.8 \\
\hline S. D. & 3.34 & 2.45 & 1.19 & 4.91 & 2.74 & 2.17 & \\
\hline $\begin{array}{l}0.01 \% \\
\mathrm{~Pb}\left(\mathrm{NO}_{3}\right)_{2}\end{array}$ & 56.1 & 4.5 & -27.8 & 9.9 & 5.0 & -10.1 & 49.9 \\
\hline S. D. & 4.12 & 1.83 & 0.87 & 1.53 & 1.39 & 1.66 & \\
\hline
\end{tabular}

8| : Maxillary left molar

Table 5 Results of discoloration $\underline{4 \mid}$ [Successive immersion of intact tooth in $0.01 \% \mathrm{~Pb}\left(\mathrm{NO}_{3}\right)_{2}$ solution (24 hours); then in $0.1 \% \mathrm{NaS}$ solution (24 hours)]

\begin{tabular}{l|rrr|rcc|c}
\multirow{2}{*}{} & \multicolumn{5}{|c|}{ Before } & \multicolumn{3}{c|}{ After } & \\
\cline { 2 - 7 } & $\mathrm{L}$ & $\mathrm{a}$ & $\mathrm{b}$ & $\mathrm{L}$ & $\mathrm{a}$ & $\mathrm{b}$ & $\mathrm{E}$ \\
\hline $\begin{array}{l}\text { Enamel } \\
\begin{array}{l}\text { Region } \\
\text { of Tooth }\end{array}\end{array}$ & 54.2 & 4.5 & -25.7 & 48.0 & 4.9 & -13.4 & 13.8 \\
\hline $\begin{array}{l}\text { Cementum } \\
\text { Region } \\
\text { of Tooth }\end{array}$ & 60.5 & 6.5 & -23.3 & 22.9 & 0.8 & -13.5 & 39.3 \\
\hline
\end{tabular}

4: Maxillary left premolar

Table 6 Results of discoloration $\sqrt{8}$ [Intact tooth immersed in $0.1 \% \mathrm{Na}_{2} \mathrm{~S}$ solution (24 hours) ]

\begin{tabular}{|c|c|c|c|c|c|c|c|}
\hline & \multicolumn{3}{|c|}{ Before } & \multicolumn{3}{|c|}{ After } & \multirow[b]{2}{*}{$E$} \\
\hline & $\mathrm{L}$ & $a$ & b & $\mathrm{L}$ & $a$ & b & \\
\hline $\begin{array}{l}\text { Enamel } \\
\text { Region } \\
\text { of Tooth }\end{array}$ & 58.9 & 7.1 & -35.5 & 57.1 & 4.0 & -33.1 & 4.3 \\
\hline $\begin{array}{l}\text { Cementum } \\
\text { Region } \\
\text { of Tooth }\end{array}$ & 56.7 & 8.5 & -30.5 & 26.5 & 3.5 & -17.5 & 33.3 \\
\hline
\end{tabular}

8: Mandibular left molar 


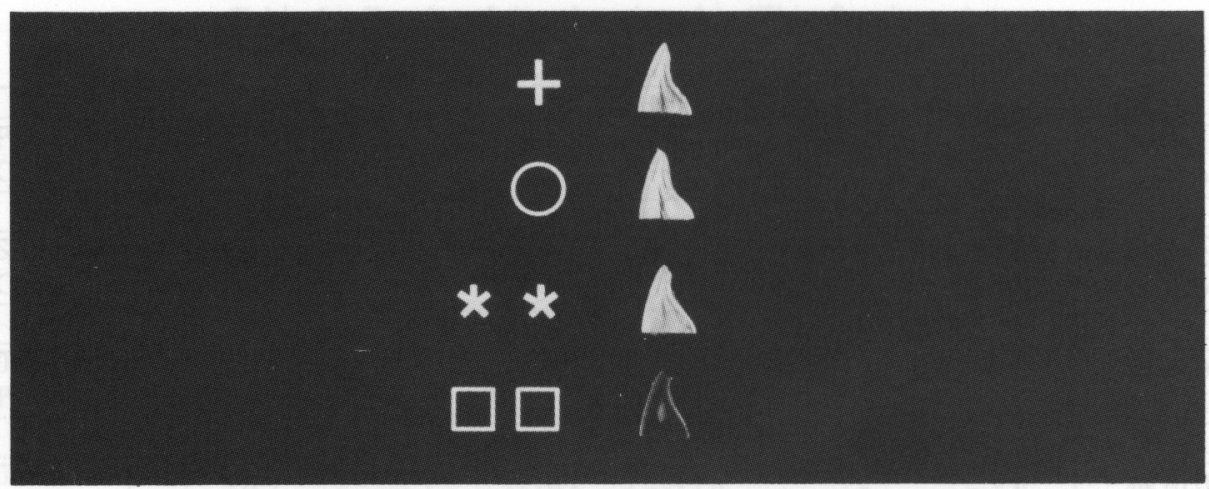

+ Immersed in distilled water (24 hours): Immersed in $0.1 \% \mathrm{Na}_{2} \mathrm{~S}$ solution ( 24 hours): Controls

* * Successive immersion in $0.001 \% \mathrm{~Pb}\left(\mathrm{NO}_{3}\right)_{2}$ solution (24 hours); then in $0.1 \% \mathrm{Na}_{2} \mathrm{~S}$ solution ( 24 hours)

$\square$ Successive immersion in $0.01 \% \mathrm{~Pb}\left(\mathrm{NO}_{3}\right)_{2}$ solution (24 hours); then in $0.1 \% \mathrm{Na}_{2} \mathrm{~S}$ solution ( 24 hours)

$$
\text { temp. }=37^{\circ} \mathrm{C}
$$

Fig. 1 Effect of immersion in $\mathrm{Na}_{2} \mathrm{~S}$ solution on $\mathrm{Pb}$-contaminated thin specimens of extracted tooth $(\underline{1 \mid})$

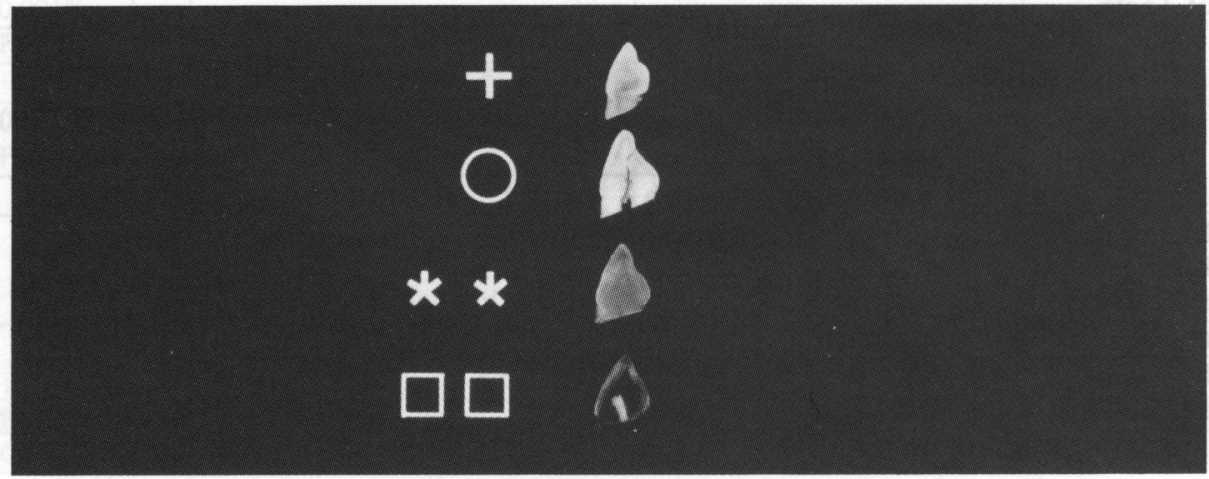

+ Immersed in distilled water (24 hours):

Immersed in $0.1 \% \mathrm{Na}_{2} \mathrm{~S}$ solution ( 24 hours): Controls

* * Successive immersion in $0.001 \% \mathrm{~Pb}\left(\mathrm{NO}_{3}\right)_{2}$ solution (24 hours); then in $0.1 \% \mathrm{Na}_{2} \mathrm{~S}$ solution ( 24 hours)

Successive immersion in $0.01 \% \mathrm{~Pb}\left(\mathrm{NO}_{3}\right)_{2}$ solution (24 hours); then in $0.1 \% \mathrm{Na}_{2} \mathrm{~S}$ solution ( 24 hours)

$$
\text { temp. }=37^{\circ} \mathrm{C}
$$

Fig. 2 Effect of immersion in $\mathrm{Na}_{2} \mathrm{~S}$ solution on $\mathrm{Pb}$-contaminated thin specimens of extracted tooth $(\underline{3 \mid})$ 


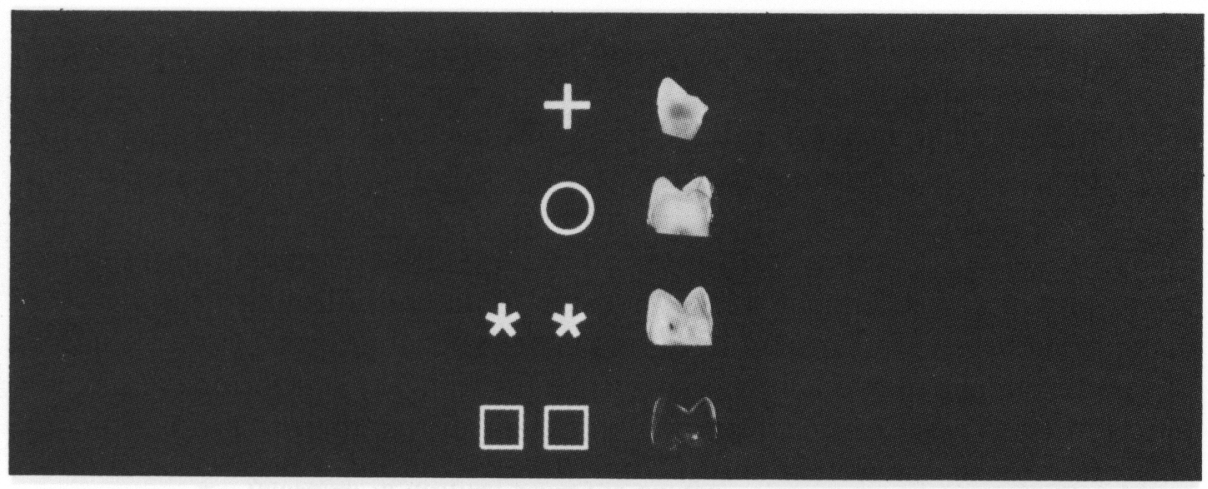

$\left.\begin{array}{l}+ \text { Immersed in distilled water ( } 24 \text { hours): } \\ \text { Immersed in } 0.1 \% \mathrm{Na}_{2} \mathrm{~S} \text { solution ( } 24 \text { hours): }\end{array}\right\}$ Controls

* $*$ Successive immersion in $0.001 \% \mathrm{~Pb}\left(\mathrm{NO}_{3}\right)_{2}$ solution (24 hours); then in $0.1 \% \mathrm{Na}_{2} \mathrm{~S}$ solution ( 24 hours)

Successive immersion in $0.01 \% \mathrm{~Pb}\left(\mathrm{NO}_{3}\right)_{2}$ solution (24 hours); then in $0.1 \% \mathrm{Na}_{2} \mathrm{~S}$ solution (24 hours)

$$
\text { temp. }=37^{\circ} \mathrm{C}
$$

Fig. 3 Effect of immersion in $\mathrm{Na}_{2} \mathrm{~S}$ solution on $\mathrm{Pb}$-contaminated thin specimens of extracted tooth ( $\underline{4 \mid})$

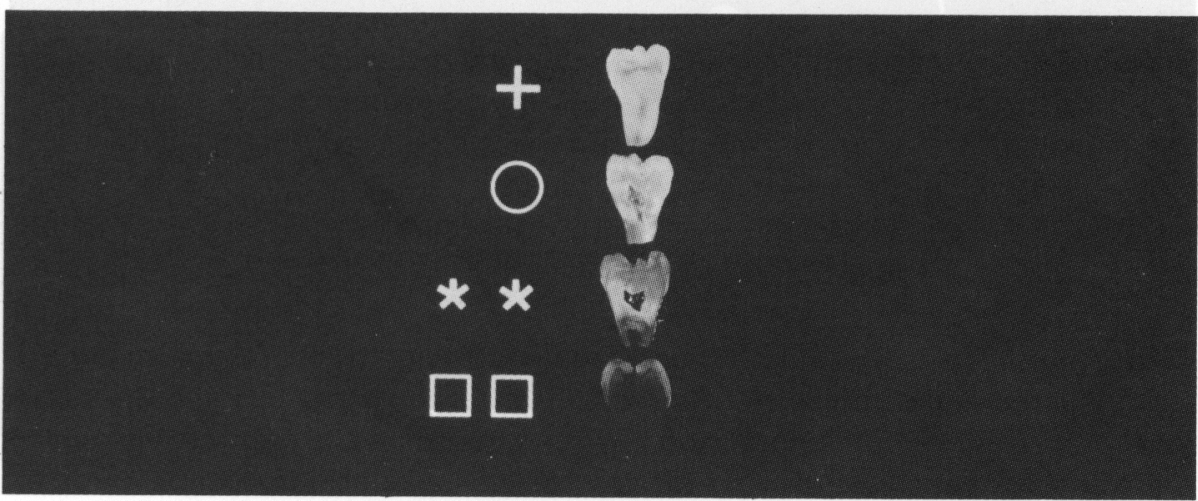

+ Immersed in distilled water ( 24 hours): Immersed in $0.1 \% \mathrm{Na}_{2} \mathrm{~S}$ solution ( 24 hours):

\section{Controls}

* Successive immersion in $0.001 \% \mathrm{~Pb}\left(\mathrm{NO}_{3}\right)_{2}$ soluion (24 hours);

then in $0.1 \% \mathrm{Na}_{2} \mathrm{~S}$ solution (24 hours)

Successive immersion in $0.01 \% \mathrm{~Pb}\left(\mathrm{NO}_{3}\right)_{2}$ solution (24 hours)

$$
\text { temp. }=37^{\circ} \mathrm{C}
$$

Fig. 4 Effect of immersion in $\mathrm{Na}_{2} \mathrm{~S}$ solution on $\mathrm{Pb}$-contaminated thin specimens of extracted tooth $(\underline{8 \mid})$ 


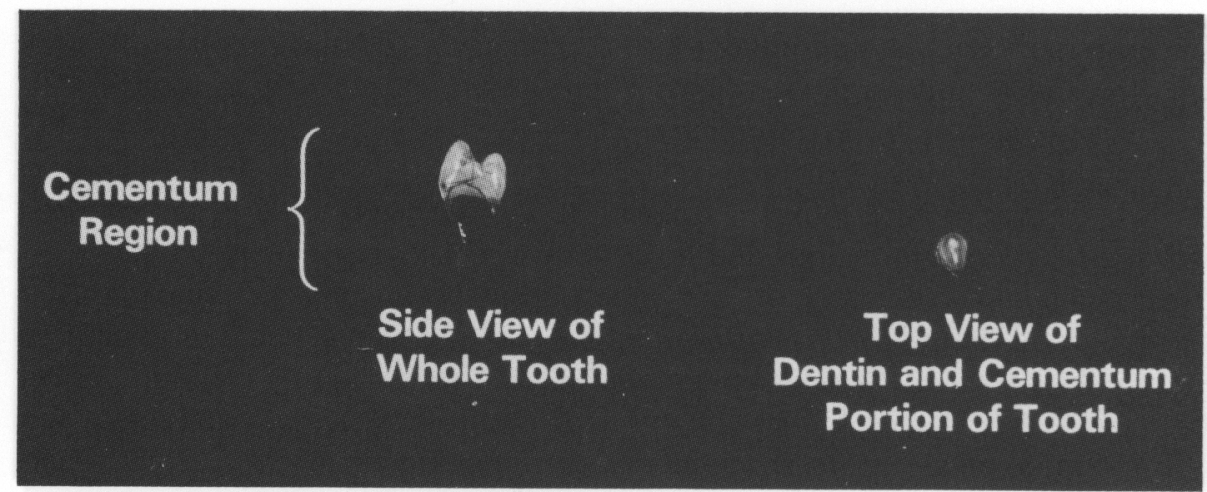

Successive immersion in $0.01 \% \mathrm{~Pb}\left(\mathrm{NO}_{3}\right)_{2}$ solution (24 hours) then in $0.1 \% \mathrm{Na}_{2} \mathrm{~S}$ solution (24 hours)

$$
\text { temp. }=37^{\circ} \mathrm{C}
$$

Fig. 5 Effect of immersion in $\mathrm{Na}_{2} \mathrm{~S}$ solution on $\mathrm{Pb}$-contaminated intact tooth structure ( $4 \mid$ )

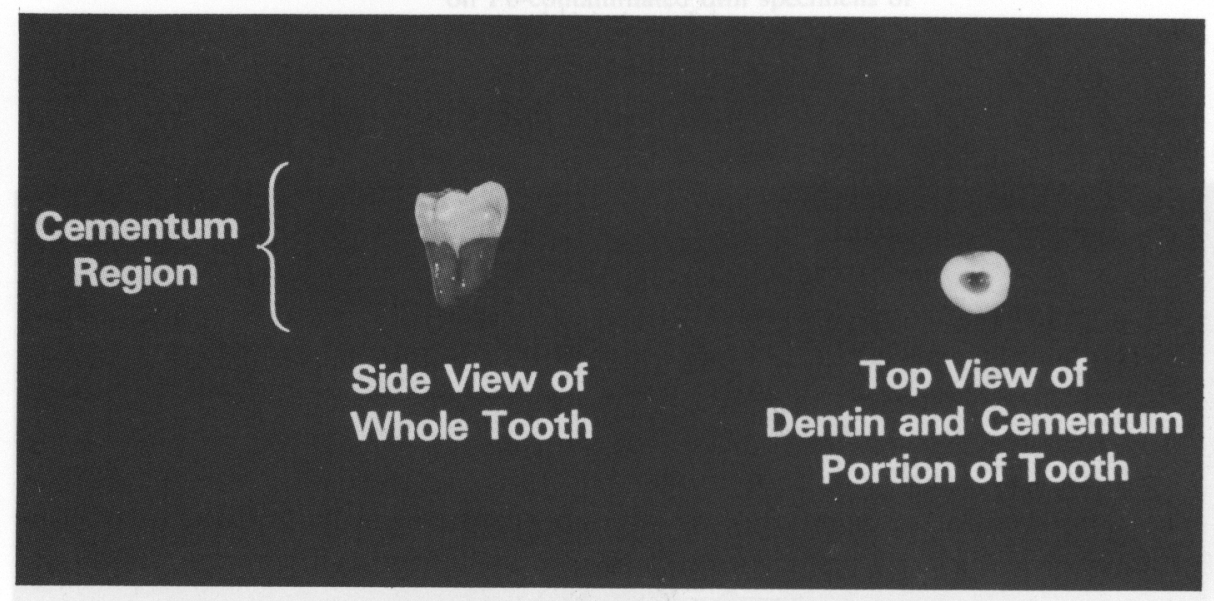

Successive immersion in $0.1 \% \mathrm{Na}_{2} \mathrm{~S}$ solution ( 24 hours) temp. $=37^{\circ} \mathrm{C}$

Fig. 6 Effect of immersion in $\mathrm{Na}_{2} \mathrm{~S}$ solution on intact tooth structure $(\underline{8 \mid})$ 


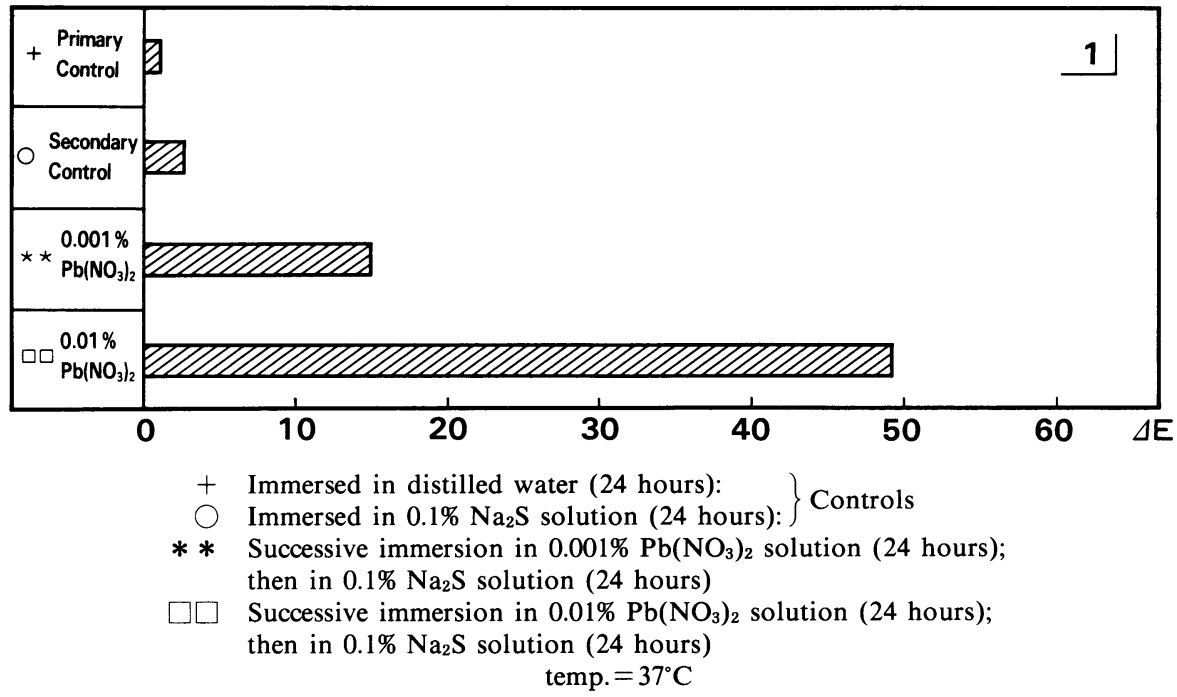

Fig. 7 Effect of immersion in $\mathrm{Na}_{2} \mathrm{~S}$ solution on $\mathrm{Pb}$-contaminated thin specimens of extracted tooth

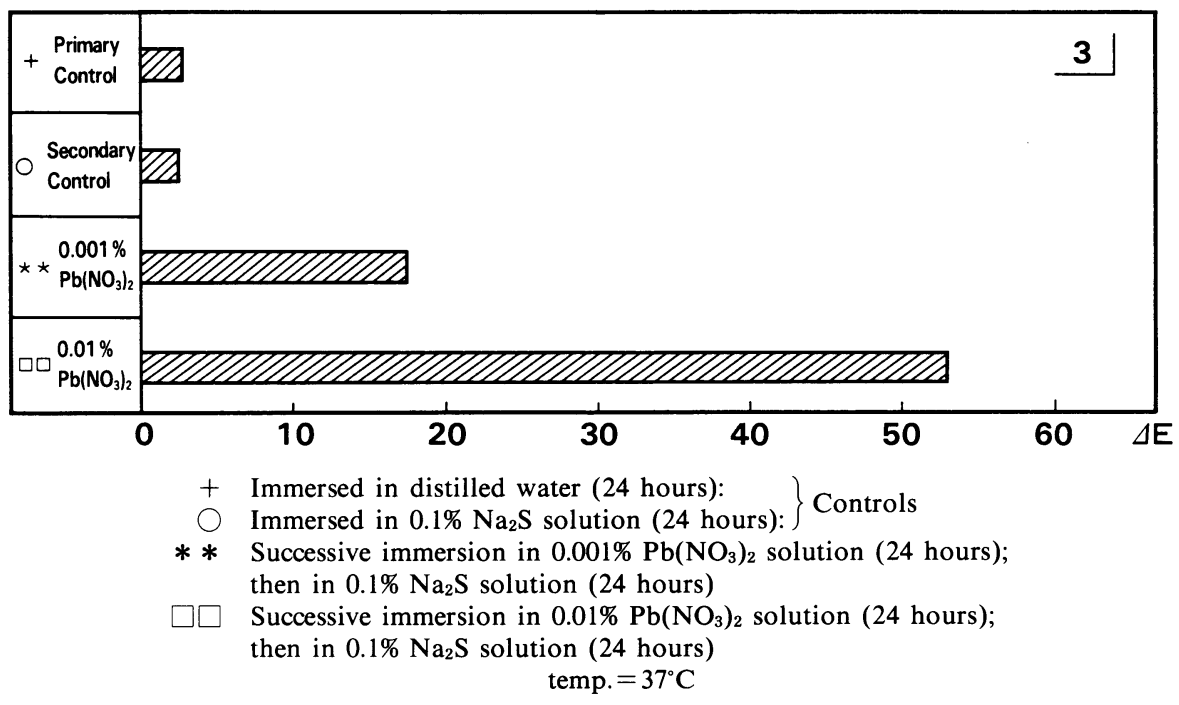

Fig. 8 Effect of immersion in $\mathrm{Na}_{2} \mathrm{~S}$ solution on $\mathrm{Pb}$-contaminated thin specimens of extracted tooth 


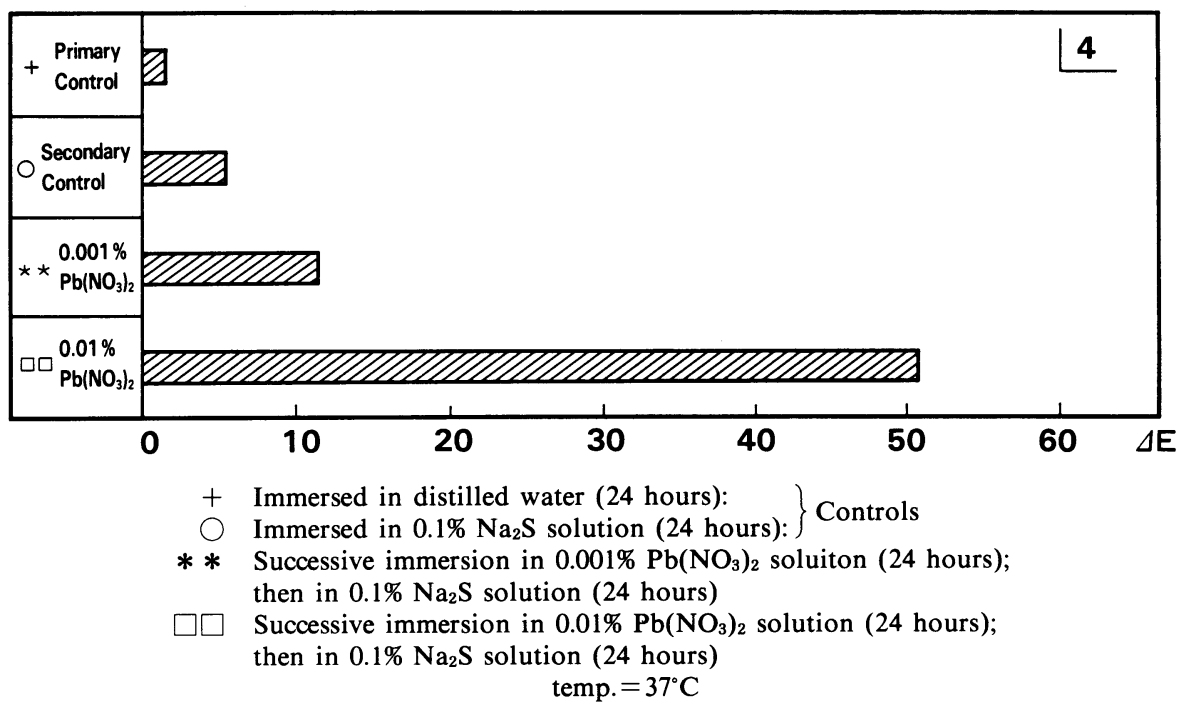

Fig. 9 Effect of immersion in $\mathrm{Na}_{2} \mathrm{~S}$ solution on $\mathrm{Pb}$-contaminated thin specimens of extracted tooth

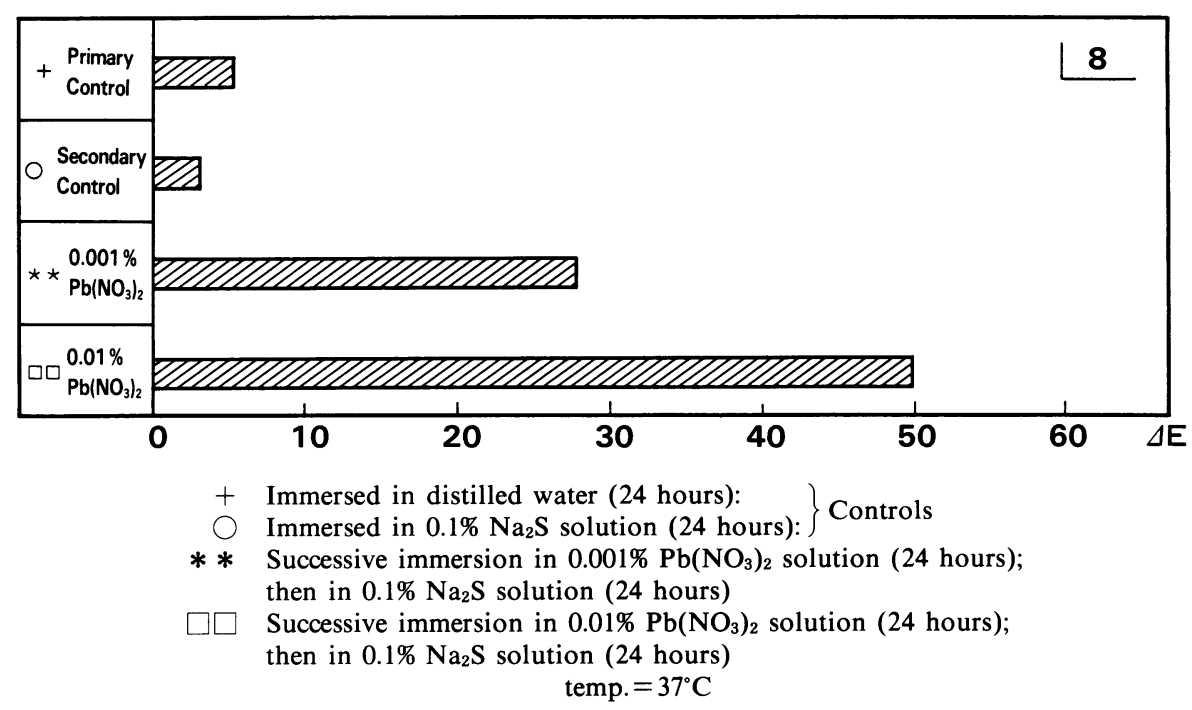

Fig. 10 Effect of immersion in $\mathrm{Na}_{2} \mathrm{~S}$ solution on $\mathrm{Pb}$-contaminated thin specimens of extracted tooth 


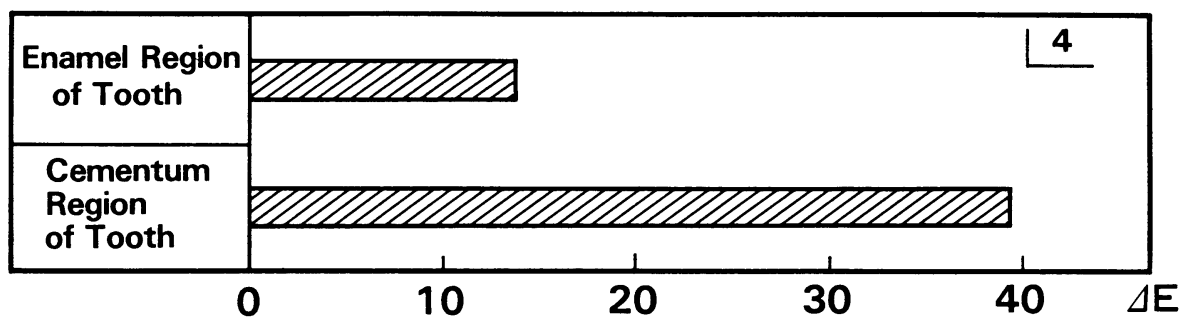

Successive immersion in $0.01 \% \mathrm{~Pb}\left(\mathrm{NO}_{3}\right)_{2}$ solution (24 hours); then in $0.1 \% \mathrm{Na}_{2} \mathrm{~S}$ solution ( 24 hours)

temp. $=37^{\circ} \mathrm{C}$

Fig. 11 Effect of immersion in $\mathrm{Na}_{2} \mathrm{~S}$ solution on $\mathrm{Pb}$-contaminated intact tooth

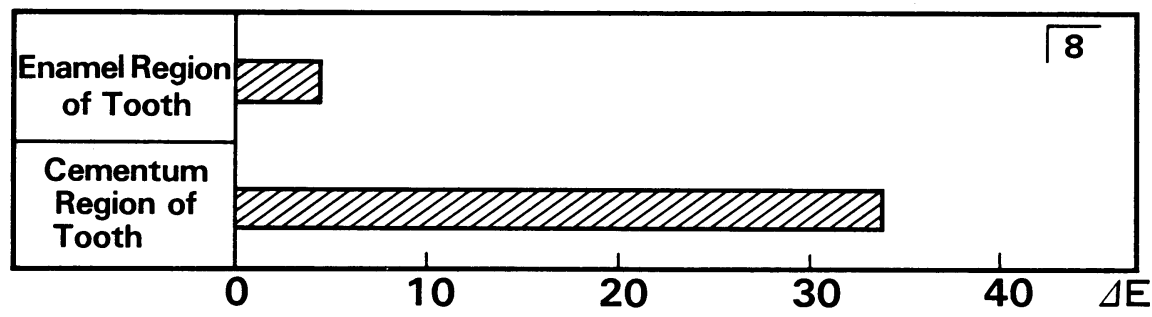

Successive immersion then in $0.1 \% \mathrm{Na}_{2} \mathrm{~S}$ solution ( 24 hours)

temp. $=37^{\circ} \mathrm{C}$

Fig. 12 Effect of immersion in $\mathrm{Na}_{2} \mathrm{~S}$ solution on intact tooth 


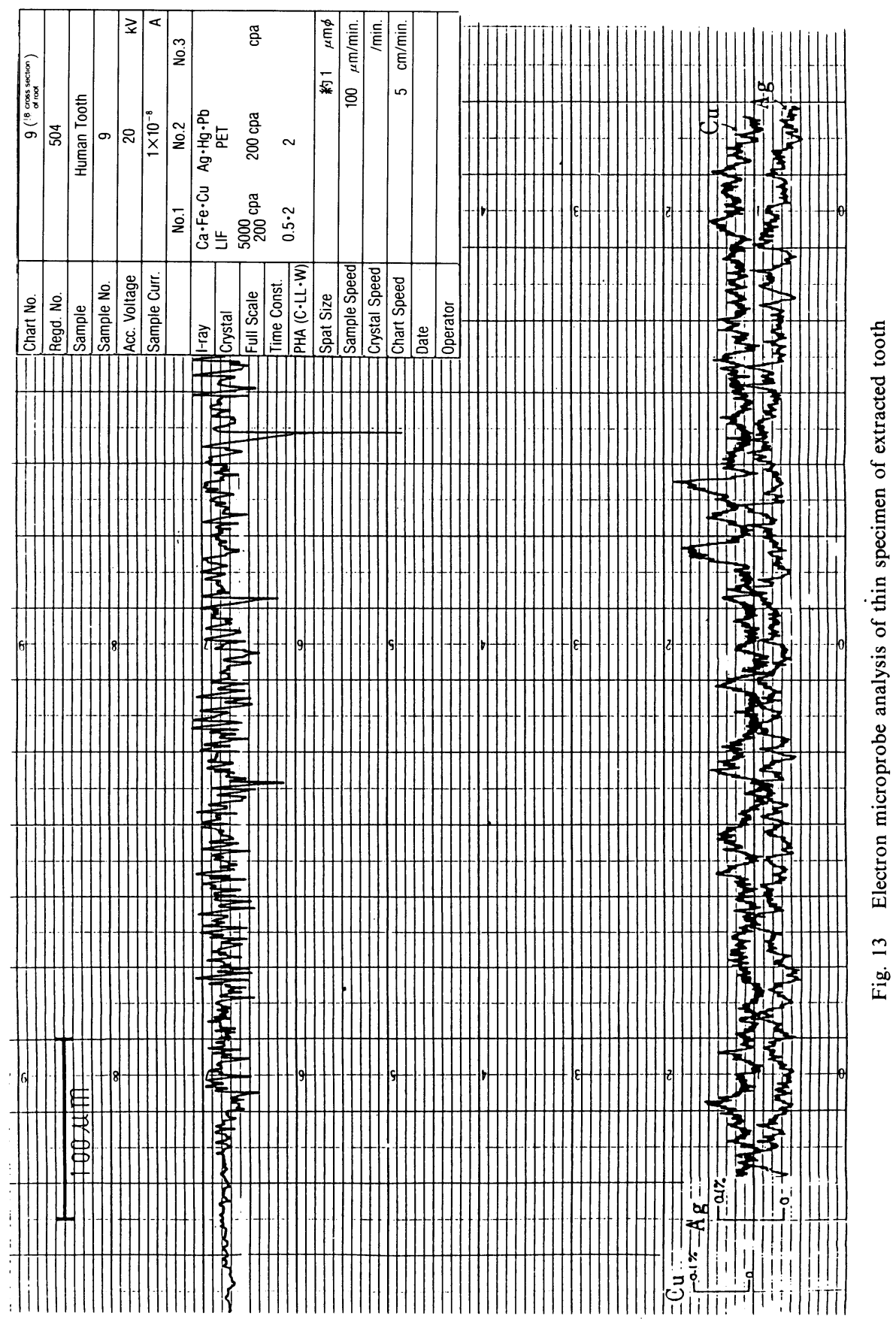




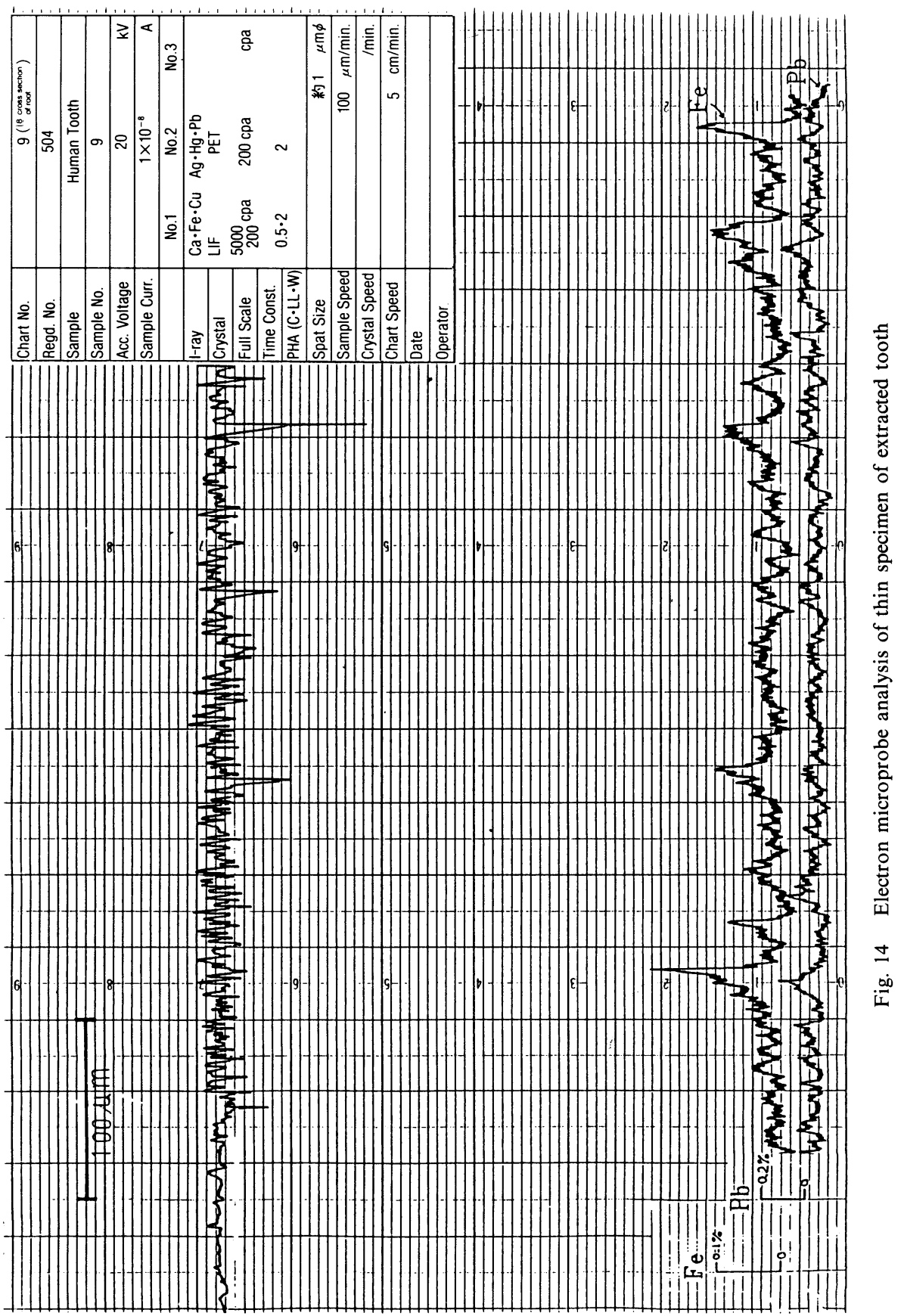




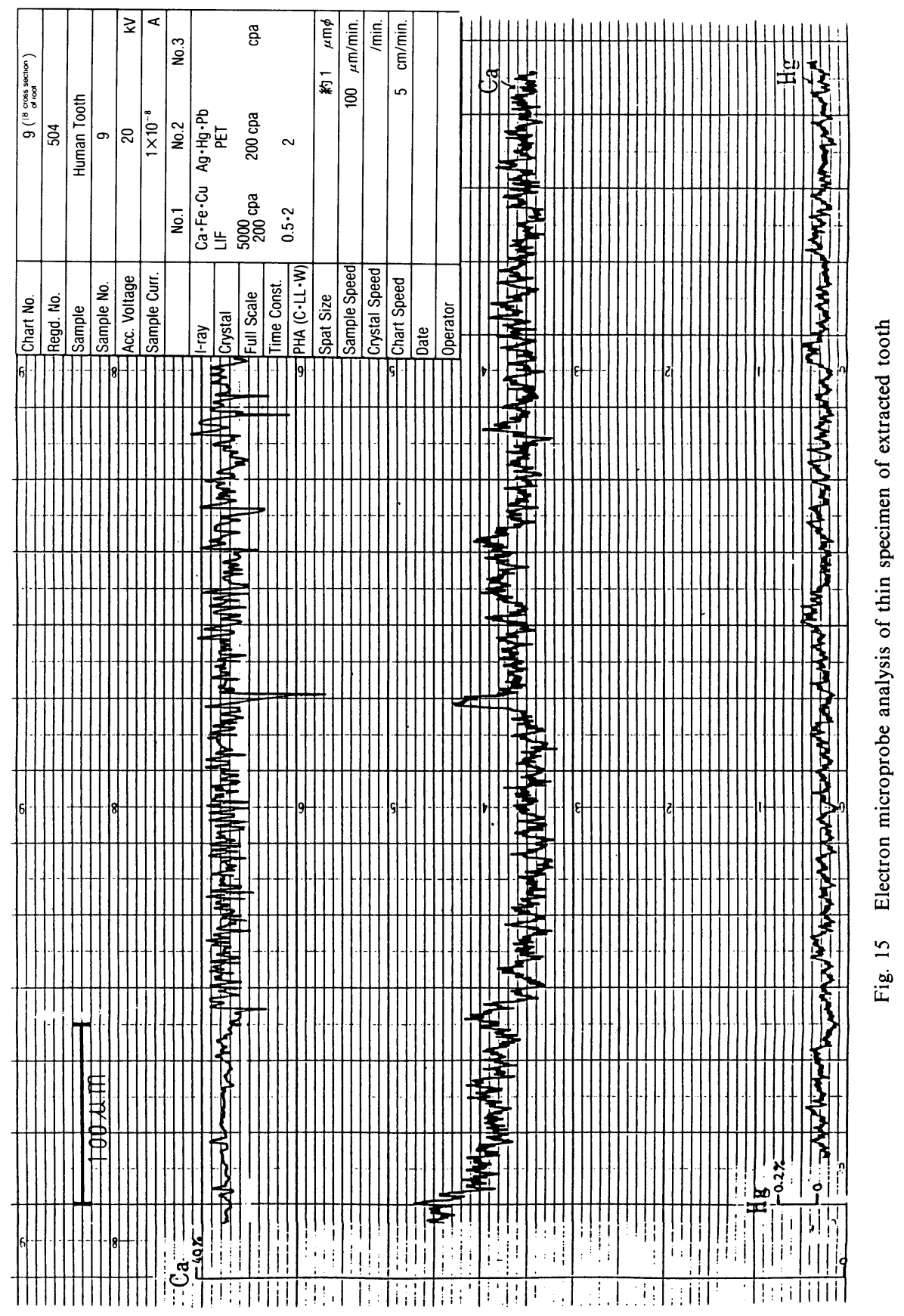

